\title{
Grief and Fantasy in Children Aged 7 to 9 Years: A Case Study
}

\author{
Ellen Fernanda Klinger* \\ Ph.D. student of the Graduate Program in Psychology of the Pontifical Catholic University of Goiás and \\ Professor at the University of Gurupi \\ University Sector, CEP: 74605-010, Goiania-GO, Brazil
}

Fábio Jesus Miranda

Professor of the Graduate Program in Psychology of the Pontifical Catholic University of Goiás University Sector, CEP: 74605-010, Goiania-GO, Brazil

Daniela Ponciano Oliveira

Master student of the Graduate Program in Psychology, Federal University of Pará

University Campus of Guamá, Belém-PA, Brazil

\begin{abstract}
Grieving situations are inevitable and are part of human development, as well as being necessary for the constitution and formation of the subject. The death of a loved one can be felt intensely and painfully and, when it occurs in childhood, it can generate strong reactions, anguish, and sadness during the grieving process. This article aims to investigate children's grief and fantasies related to death. The study was developed at a Clinical School of Psychology, in the south of the state of Tocantins, with nine (9) children aged between 7 and 9 years as participants. The information from the interviews with the parents was interpreted, in playful interviews and application of the HTP and BDS - IJ tests with the children. The results suggest that the type of death, how it was communicated and the child's bond with the deceased person are aspects that must be considered, when it comes to the loss and its consequences in child development since they can operate as generators of conflicts involving ambivalent feelings and fantasies, such as guilt, omnipotence, and rejection, in addition to the perception of helplessness. The conflicts and feelings expressed by the children demonstrated the child's understanding of death, with the crossing of feelings such as fear and insecurity about changes in the family structure and dynamics. Such facts reinforce the need for support measures, both for children and for the weakened family
\end{abstract}

Keywords: Death, grief, child, conflict, fantasy.

DOI: $10.7176 /$ RHSS/11-8-01

Publication date: April $30^{\text {th }} 2021$

\section{Introduction}

The theme of mourning is still treated with fear, by most people, and of the most varied cultures, because it is accompanied by a certain discomfort and perception of impotence in the face of the irreversibility of death. Despite being a universal experience, the mourning for the loss of those who love can be experienced in a frightening and disorganized way. This process provokes questions and reflections and life then begins to be rethought, as well as relationships tend to be reorganized.

Situations of loss and mourning are painful and inevitable, but likewise, they are essential for the constitution and development of the individual. They are not given exclusively by the death of a close person, but are present at the birth of a brother, who establishes the place of the eldest son in the family; in the change of life cycle, such as from childhood to adolescence; in the separation of parents; changing schools or city; the loss of a job or relationship or a pet; the loss of one's health or loved ones (Aberastury, 2012/1982). The mourning comes for the loss of the previous condition, according to Kovács (1992). However, unlike other losses, the death of a loved one, due to their strong affective investment, requires greater energy for the reorganization of the bereaved (Andrade, Mishima-Gomes \& Barbieri, 2018).

Socially, death is experienced by interfering with the family. People close to the deceased are affected in different ways and intensities and should be considered the moment of their development, the circumstance in which the death occurred, and the relationship with the deceased. However, society does not prepare and does not know how to deal with death: it limits the time to suffer, to feel the regret of losing someone dear and considers, in its way, that it is a weakness (Bittencourt, Quintana \& Velho, 2011).

With her contributions focused on the early stages of development, psychoanalyst Melanie Klein (1996/1940) considers mourning as part of development, addressing losses and mourning under the theory of positions. In the same way that Freud contributions (2011/1917) served as an initial reference to Klein theorizations about child development, the author also influenced the first publications of Donald Winnicott on the beginnings of childhood, the author whose lenses were taken on loan, for the interpretation of the information of this research. 
However, even without completely disregarding Klein contributions, Winnicott (1975/1971) followed new directions and returned his theory to primitive emotional development and the role of the environment/mother good enough. One of the aspects that differentiate his theory from Klein is about the depressive position, rewritten by the author as a phase of concern. In this regard, there is the acceptance of responsibility for the destructiveness linked to living, instinctive life, anger, and frustration. For concern and responsibility, the continued presence of the object of love is necessary; and only then is there the opportunity for reparation ${ }^{1}$. Therefore, Winnicott (2005/1960) presents in his theory the facilitating environment as fundamental to sound development.

The sufficiently good environment can offer holding ${ }^{2}$ and enables the spontaneous and creative expression of the child in the world. Initially, it appears by the care and presentation of objects by the mother, alternating presence and absence in a measure that neither occurs in excess (Winnicott, 1983a/1960).

Thus, Winnicott (1975/1971) theorizes that, from the first interactions and absences, space is opened for the baby to differentiate from the mother and find resources to deal with the faults and frustrations, by perceiving himself as a being separated from her. The scholar also introduces the concepts of objects and transitional phenomena. Transitional objects are understood as the origin of the symbolization process, the passage between the relationship with subjective objects to objectively perceived objects; therefore, the internal and external world. Transitional objects are an early way of seeking elements to deal with the gradual separation of the maternal figure and, thus, to assist in the passage through loss.

Winnicott states (2000/1958) that failures in the provision of sufficiently good environmental support can have consequences for states of deprivation or deprivation. Deprivation occurs in the phase of the absolute dependence of the baby about the environment/mother, as a result of abandonment before the development of the mind and the differentiation between the I and the non-me. In the state of deprivation, the child has a sense of the environment, and the lack can occur due to the abrupt withdrawal of sufficiently good care that the child received at the beginning of life or by the experience of the child's affliction, felt as intolerable in the face of loss, as in situations involving loss by death (Winnicott, 2000/1958).

Thus, for children, situations involving the death of a loved one can provoke intense reactions, anguish, and sadness, typical of the experience of grief, which can be reflected in emotional development (Barone, 2004; Winnicott, 1997). Exactly, for this reason, the environment plays a fundamental role in the mourning process, because it allows the child to continue building their own identity, giving vent to creativity (Winnicott, 2000/1958).

Creativity makes it possible to live the external reality, no matter how hard it is, because it enables ways of dealing with difficulties and allows the expression of the true self. It is so essential for the elaboration of grief that, if the ability to create is compromised, it remains only to deny the feelings derived from the experience of the loss of a loved one (Barone, 2004).

But to what extent does transitionality ${ }^{3}$ contribute to the understanding of grief? Winnicott proposes the participation of the element illusion as necessary, but to the extent that it does not fully compromise reality. Thus, it is not an only illusion or real, but an intermediate space between the pain of loss (reality) and the search for some relief in fantasy, illusion, creativity.

When considering the above, the question arises about the forms of expression of losses by children who experienced the death of someone close to them, such as parents, grandparents, siblings, or friends, reason now, in this article, to address the conflicts, fantasies and related difficulties expressed by bereaved children.

\section{Methodologic}

This article corresponds to part of the results obtained in the project "The child and death: the expression of losses, conflicts, and identifications in fairy tales," submitted to the Ethics Committee on Research with Human Beings - CEP of the University of Gurupi, with Certificate of Presentation of Ethical Appreciation - CAAE, $\mathrm{n}^{\circ}$. 08460919.7.0000.5518, having received the approval opinion of $\mathrm{n}^{\circ}$. 3.190.986.

A qualitative, longitudinal, exploratory research was carried out, characterized as a study of multiple cases, whose results of the first interviews with the children, as an initial evaluation of the participants, are presented and discussed here.

\footnotetext{
${ }^{1}$ The concept of repair or resolution for Winnicott is linked to guilt and the ability to worry about the object/person/mother to whom his aggressiveness was addressed. In healthy development, there is a benign circle of instinctive experience (aggressiveness), acceptance of responsibility/guilt, resolution or elaboration, and a true restitutive gesture that is provided by the environment that tolerates and survives attacks (Winnicott, 1983/1958).

${ }^{2}$ The holding company corresponds, in addition to the act of holding the baby, to the environment/mother that provides support through its attitude of understanding and empathy for the needs of the baby (Winnicott, 1975/1971).

${ }^{3}$ Function derived from objects and transitional phenomena, is a construct of creativity. The field of transitionality satisfies a condition of absolute dependence on the environment/mother that would constitute, the human experience in the world, which can also be understood as creativity. The use of transitional objects and the initial experiences of transitional phenomena lead to the ability to symbolize, to play and to the creative movements of the individual throughout life (Winnicott, 1975/1971).
} 
The study was developed in a Clinical School of Psychology of the University of Gurupi, located in the Tocantins, and involved nine (9) children, of both sexes, aged between seven and nine years and eleven months, who waited for care on the waiting list of the care service of the said Clinic. The children composed the list due to the spontaneous search of those responsible for the referral of schools, health services, or social assistance.

The beginning of the construction of the information occurred after the exposure of the objectives of the research and its importance, to the person responsible for each child, with the settlement of voluntary participation and signing of the Informed Consent Form - TCLE. The interviews with the children were filmed and with the guardians were recorded in audio. For the children, the Term of Nod containing the explanation about the research was elaborated in language consistent with each age group, whose signature or mark/record expressed the child's active place as a prominent subject in the study.

In the first contact with those responsible, an interview was conducted to construct information about the child's life history, history of the death of the next of them, the record of how the death to the child was reported, the family impact, and the perception of those responsible about how the child received and understood the loss. With the children, an individual playful interview was conducted, using free play as a resource (Trinca, 1997), application of the Baptist Depression Scale in the Infant-Juvenile version - BDS-IJ (Baptista, 2018), and the House, Tree, Person - HTP test (Buck, 2003).

BDS - IJ is an instrument consisting of twenty-seven (27) items of depressive symptomatology and among its descriptors are depressed mood, loss or decrease of pleasure, crying, hopelessness, helplessness, indecision, feeling of inadequacy and inadequacy, lack of dependence, negativism, dodging social situations, falling productivity, uselessness, exacerbated self-criticism, guilt, decreased concentration, thought of death, low selfesteem, lack of perspective on the present, altered appetite, weight change, insomnia or hypersomnia, slowness or psychomotor agitation, fatigue and irritation. It can be applied in the age group from 7 to 18 years, and the lower the score, the lower the depressive symptomatology presented by the individual.

HTP consists of a projective test in which they are performed by evaluating three simple drawings, a house, a tree, and a person. Then, a survey is carried out with questions related to the drawings made. This instrument allows the analysis of certain personality traits, areas that are in conflict, feelings, and projections (Buck, 2003).

The use of projective techniques aims to create interpretative hypotheses about personality and other elements experienced or perceived by the subject. Through projective techniques, it is possible to evaluate the external projection that the individual has of a certain element (Fensterseifer \& Werlang, 2008). The graphic tests show the most regressive and pathological aspects of the evaluation.

After contact with the guardians and initial interviews, the recordings and recordings were transcribed and the tests analyzed according to the interpretation manuals. The method of interpretation of the information of the interviews followed the basis in psychoanalysis of Winnicotian bias regarding the interpretation and deepening of the contents brought, as well as in the content analysis (Bardin, 2011) for the identification and reading of the themes that stood out.

\section{Results}

The results of the study were ordered and presented qualitatively, according to the items of the construction of the information. To protect and identity of the participants, the use of the capital letter $\mathrm{C}$ (Ex. C1, C2) followed by a numeral for children and R (R1, R2) will also be adopted, followed by a numeral for those responsible.

Table 1 presents a summarized overview of the initial interviews with guardians, in which the information was subdivided into: a) Age of the child; b) Sex; c) Who has died; d) Cause of death; (e) time elapsed from death; f) Who communicated; g) Explanation of death; h) Child reaction. 
Table 1 - Synthesis of clinical cases.

\begin{tabular}{|c|c|c|c|c|c|c|c|}
\hline $\begin{array}{l}\text { Age of } \\
\text { child }\end{array}$ & Sex & $\begin{array}{l}\text { Who has } \\
\text { died }\end{array}$ & $\begin{array}{c}\text { Cause of } \\
\text { death }\end{array}$ & $\begin{array}{l}\text { Time } \\
\text { Months }\end{array}$ & $\begin{array}{c}\text { Who } \\
\text { communicated }\end{array}$ & $\begin{array}{c}\text { Explanation of } \\
\text { death }\end{array}$ & $\begin{array}{l}\text { Child } \\
\text { reaction }\end{array}$ \\
\hline $\begin{array}{c}\mathrm{C} 1 / \\
8 \\
\text { years }\end{array}$ & $\mathrm{M}$ & $\begin{array}{l}\text { Schoolmate/fr } \\
\text { iend }\end{array}$ & $\begin{array}{l}\text { Heart } \\
\text { problem }\end{array}$ & 1 & $\begin{array}{l}\text { Mother and } \\
\text { school }\end{array}$ & God needed him. & $\begin{array}{l}\text { Crying, } \\
\text { questions, } \\
\text { fear. }\end{array}$ \\
\hline $\begin{array}{c}\text { C2/ } \\
8 \\
\text { years }\end{array}$ & $\mathrm{F}$ & $\begin{array}{l}\text { Grandmother } \\
\text { and uncle }\end{array}$ & Accident & 6 e 8 & Mother & $\begin{array}{l}\text { News along with } \\
\text { parents/ attempt to } \\
\text { omit. }\end{array}$ & $\begin{array}{l}\text { Worry, } \\
\text { revolt, } \\
\text { crying. }\end{array}$ \\
\hline $\begin{array}{c}\text { C3/ } \\
7 \\
\text { years }\end{array}$ & M & $\begin{array}{l}\text { Grandmother } \\
\text { and uncle }\end{array}$ & Accident & 6 e 8 & Mother & $\begin{array}{l}\text { News along with } \\
\text { parents/ attempt to } \\
\text { omit }\end{array}$ & $\begin{array}{c}\text { Restlessness, } \\
\text { do not talk. }\end{array}$ \\
\hline $\begin{array}{c}\text { C4/ } \\
9 \\
\text { years }\end{array}$ & $\mathrm{F}$ & Father & Murder & 7 & Third & $\begin{array}{l}\text { News along with } \\
\text { grandmother }\end{array}$ & $\begin{array}{l}\text { Sadness, } \\
\text { fainting, } \\
\text { avoid } \\
\text { talking, } \\
\text { crying. }\end{array}$ \\
\hline $\begin{array}{c}\text { C5/ } \\
9 \\
\text { years }\end{array}$ & $\mathrm{F}$ & Grandmother & $\begin{array}{l}\text { Liver } \\
\text { cirrhosis }\end{array}$ & 6 & Third & $\begin{array}{c}\text { He said his } \\
\text { grandmother was } \\
\text { dead. }\end{array}$ & $\begin{array}{l}\text { Sadness, } \\
\text { crying. }\end{array}$ \\
\hline $\begin{array}{c}\text { C6/ } \\
8 \\
\text { years }\end{array}$ & $\mathrm{F}$ & Grandmother & $\begin{array}{l}\text { Liver } \\
\text { cirrhosis }\end{array}$ & 6 & Third & $\begin{array}{l}\text { He said his } \\
\text { grandmother was } \\
\text { dead. }\end{array}$ & $\begin{array}{l}\text { Not talk } \\
\text { about. }\end{array}$ \\
\hline $\begin{array}{c}\text { C7/ } \\
8 \\
\text { years }\end{array}$ & M & Sister & Suicide & 11 & $\begin{array}{l}\text { Third and then } \\
\text { the mother }\end{array}$ & $\begin{array}{c}\text { She became a little } \\
\text { star. }\end{array}$ & $\begin{array}{l}\text { Concern for } \\
\text { father and } \\
\text { brothers. }\end{array}$ \\
\hline $\begin{array}{c}\mathrm{C} 8 / \\
8 \\
\text { years }\end{array}$ & M & Sister & Suicide & 11 & $\begin{array}{l}\text { Third and then } \\
\text { the mother }\end{array}$ & $\begin{array}{c}\text { She became a little } \\
\text { star. }\end{array}$ & $\begin{array}{l}\text { He won't } \\
\text { talk. }\end{array}$ \\
\hline $\begin{array}{c}\text { C9/ } \\
9 \\
\text { years }\end{array}$ & M & $\begin{array}{l}\text { Schoolmate/fr } \\
\text { iend }\end{array}$ & Murder & 11 & News on TV & $\begin{array}{l}\text { Report. } \\
\text { Later the mother } \\
\text { explained that the } \\
\text { friend had not } \\
\text { resisted. to the } \\
\text { wound and passed } \\
\text { away. }\end{array}$ & $\begin{array}{c}\text { Crying, fear, } \\
\text { and } \\
\text { somatization } \\
\text {. }\end{array}$ \\
\hline
\end{tabular}

In the information contained in Table 1, it is possible to notice that the deaths were sudden and that there was no time to prepare the child and the communicator for the news to be given. Among the pairs of siblings, $\mathrm{C} 2-\mathrm{C} 3 / \mathrm{C} 5-\mathrm{C} 6 / \mathrm{C} 7-\mathrm{C} 8$, although they live in the same environment and have close ages, the reactions exposed by the children of each pair were different from each other, given the subjective aspect involving the mourning process.

Portraying the results of the tests used, Table 2 corresponds to those of the HTP (design and survey) and the observations made by the applicator during the playful interview.

Table 2 - Synthesis of HTP test results.

\begin{tabular}{cll}
\hline Child & \multicolumn{1}{c}{ HTP } & \multicolumn{1}{c}{ Interview remarks } \\
\hline C1 & $\begin{array}{l}\text { Environmental concerns, defense attitudes, inhibition, } \\
\text { inadequacy, and dependence. Omitted pupils understood as } \\
\text { poor contact with reality; omitted hands and feet interpreted as } \\
\text { guilt, helplessness, and helplessness; search for fantasy; denial } \\
\text { and non-acceptance of death. }\end{array}$ & $\begin{array}{l}\text { The child showed inhibition and } \\
\text { insecurity and expressed concern } \\
\text { about other losses, the mother and } \\
\text { close people. }\end{array}$ \\
C2 & $\begin{array}{l}\text { Anxiety; the need for support; dependence; feelings of } \\
\text { inadequacy and helplessness. The house tilted to the right and } \\
\text { without door interpreted as frailties in the home, about to } \\
\text { collapse and inaccessible; the design of the tree and the person } \\
\text { was related to the people who died (grandmother's tree and } \\
\text { orphan cousin). }\end{array}$ & $\begin{array}{l}\text { Sensitive; speaker; desirous of } \\
\text { verbalizing about traumatic events } \\
\text { involving death; expressed the lack } \\
\text { of deceased entities, school failure, } \\
\text { and the situation of conflict at } \\
\text { school; concerns about the death and } \\
\text { future of family members; has } \\
\text { nightmares about deceased ones. }\end{array}$ \\
\end{tabular}




Child HTP Interview remarks

C3 Regression; immaturity; impulsivity; fantasy and distancing from reality. In the drawing of the house, he made the suspended rabbit hole, interpreted as poor contact with reality, search for help, and escapes in fantasy. The rabbit hole is often portrayed as a kind of hole in a slope of the land, where the animal hides, which indicates concern about death and identification with dead relatives and disorganization.

C4 Stiffness; retracting; insecurity; seeking compensation; feelings of inadequacy; critic, erased his drawing a few times and took the pencil to leave the lines of the house straight, attitudes understood as the need for repair and safety; he designed a dispensation, interpreted as possession of content shaded for himself and the large tree, read as a search for satisfaction and fantasy about his environment.

C5 Need for support; guilt; feeling of rejection; designed the large tree, with many fruits, and scar, suggest a search for super compensatory satisfaction, fantasy, and trauma; numerous details in the three drawings interpreted as high anxiety.
Referred after the complaint to the Guardianship Council for not attending school; aggressiveness; restlessness and indiscipline.

Agitated, he presented contents of omnipotence and death as an enemy. Losses from family changes. He had a close relationship with his father but avoided talking about him. He was ambivalent between receptive and suspicious behavior during the playful interview.

Referred to the temporary home after the loss of maternal custody. Communicative, demonstrated adequate understanding and interest in own participation; affective deficiency; crying; feeling helpless; he felt guilty about his grandmother's death and homesickness.

C7 Search for compensation; retracting; environmental pressures;
C6 Regression; insecurity; search for fantasy; in the house, he drew himself and his sister separated from the family, as it occurred; absence of the door interpreted as to its inaccessibility, its isolation, and feeling of being trapped when being removed from the home itself. fantasy; immaturity; insecurity; anxiety.

Sent by the temporary home, where she already lived after the loss of maternal custody. Docile, delicate, soft-spoken, and soft-spoken. He passed with his sister through deprivation and demonstrates not understanding or denying the situation. I manifest unpleased behavior during the playful interview.

He presented himself spontaneously, with a desire to speak of himself and understand what happened to his sister. Strong connection and concern for the family. You think you look like your dead sister.

C8 Insecurity; retracting; stress factor; anxiety; concern for the environment; inadequacy defense.

C9 Retract; dependence; strong tension; anxiety and need to defend yourself; small tree and house, drawn in the lower left quadrant indicating insecurity and inadequacy in dealing with the environment and relationships. All very small drawings.
Slightly withdrawn, but participatory. It is quieter, introspective. He showed interest in the group and in having room to express himself.

Shy; insecure; he had a hard time focusing his gaze, choosing toys, and verbalizing any aspect of his life. This behavior occurs in other environments, according to the mother and the referral of the school.

Regarding the results of the BDS-IJ, the children presented scores within the limits of positive behavior, not indicating depressive symptoms, according to the norms of interpretation of the scale (Baptista, 2018). However, it was note point that five (5) children(C2, C5, C7, C8, and C9) answered feeling guilty a few times and four (4), $(\mathrm{C} 2, \mathrm{C} 3, \mathrm{C} 7$, and $\mathrm{C} 8)$, indicated responses related to insecurity regarding their abilities and intelligence.

Participants C1, C4, and C9 presented greater resistance and discomfort when answering the test as if they were afraid to put their grief in words, even if written; interpreted, by the researcher, as a demonstration of not being prepared to speak or even because they are surprised by the statements contained in the test. At times, they would be silent, shaking their heads in negative, or they would verbalize, "No!" (C1 and C9), "I never! What a 
crazy thing!" (C4).

It should be noted that the answer sheet was given, so that the child could read and mark their alternatives, while the researcher paused ly read each of the sentences of the test, always explaining what was not clear to the child. Except for $\mathrm{C} 7$ and $\mathrm{C} 8$, the children preferred to follow the reading and talk about their answers. At all times we sought to establish rapport, as well as to express that there were no right or wrong answers, but ways of how people can feel.

\section{Discussion}

In the interpretation of the results collected from the interviews and tests, three thematic axes were highlighted, involving: the type or circumstance of death; the communication of death and family interaction, and the expression of conflicts and fantasies by the child. As much as in this article these topics appear separately, it should be noted that they meet, intertwine.

\subsection{Type of death}

The types of death are classified as: expected, as in cases of disease; sudden or sudden; by suicide; violence; and son (Soares \& Mautoni, 2013). The nine children participating in the study experienced a loss involving sudden death, which is also an aggravating factor for the process of mourning elaboration. It is important to point out that, when it occurs suddenly and unexpectedly, death is impactful for the whole family, since it is a type of death that does not give time for the family and close people to prepare; if it is indeed possible to be ready for the end of life. They are empty, doubts, feelings of abandonment, insecurity, anger, and guilt, as well as the fear of forever losing the object of love (Worden, 2013).

In the reports of the deaths of the components of the group of this research, all were sudden, however, they differ in terms of the causes. It is worth mentioning, especially, the facts that involved two pairs, that is, between the reality of pairs $\mathrm{C} 7-\mathrm{C} 8$ and $\mathrm{C} 4-\mathrm{C}$, considering that for both there was a sudden violent death, however, in C7-C8 there was self-inflicted violence (suicide) and in C4-C9 violence caused by third parties (homicide). Also, among the deceased, three deaths occurred at ages that death is socially more difficult to understand: childhood, in which $\mathrm{C} 1$ and $\mathrm{C} 9$ lost friends who were aged between 9 and 10 years, and adolescence, in the case of $\mathrm{C} 7$ and C8 who died to her brother at the age of 14 .

The death of young people and children brings with it the sense of change in the order that man naturally has or believes as established, in which parents and grandparents burying their children and grandchildren seems inconceivable. Participants in study C1, C4, C7, C8, and C9 have the understanding of the finitude of life as an interruption and not as part of the development process. They found that children may also pass away.

It often occurs that the family needs more time to work out grief when it comes to a sudden loss. The initial reaction is despair, especially for not being allowed to say goodbye. Suicide is impactful and destructive to survivors, especially because of the emptiness of unanswered questions as the reason for the act; selfrecrimination for not having perceived the intention of suicide, in addition to the monitoring of shame and social stigma. In turn, in death due to violence, families are outraged, dissatisfied, and may have a desire for revenge (Soares \& Mautoni, 2013; Worden, 2013).

Participant $\mathrm{C} 1$ began to question why his friend died and to seek answers. Explanations involving a greater sense, spirituality, and Divine desire calmed him, but at the same time brought him conflict. In the interview, R1 reports that at times he observed his son talking to himself: "He said, but why if he was so good?" (R1). Here too comes the unknown, the fear generated, and the perception of death with negative meaning, something that could not happen to "good people".

About the age of the participating children and the cognitive understanding of death, as they develop, new experiences are being integrated into their lives and of any human being. Between 7 and 10/11 years, the characteristics of emotional development are the acquisition of self-control, rules, internalization of mechanisms of competence and control, as well as the formation of rigorous perception about right and wrong, (Castro \& Levandowisky, 2009), and the separation between good and evil, as happens in fairy tales (Corso \& Corso, 2006). In terms of cognitive development, between 7 and 9 years, children progress in the ability to distinguish between animated and inanimate; they make an opposition between life and death; define death from perceptual aspects, and understand it as a definitive and permanent condition. Therefore, they come across the irreversibility of the loss (Torres, 2012).

It should be noted here that, for this research, the issues related to age and grief refer to cognitive understanding, to the conformity in which the child develops; however, without it being stated or defended that specific mourning occurs in childhood or that the child does not perceive death or, still, that it has different feelings when beset by a loss by death. To confirm the position adopted in this thesis, as described, $\mathrm{C} 1$ presents the understanding of life as finite, but also brings understanding and, therefore, the conflict that dying is like a punishment, that good people are "punished". Such feelings express a mixture of anger, fear, and guilt and also demonstrate a clear distinction of right and wrong and a sense of justice, present in this age group and in the 
social treatment that is dispensed to the theme of death.

According to R2, C9 began to manifest itself more and more introspective, crying, complaining of pain. C9 had a friend murdered near the school and is afraid of returning to the place where the friend was killed. Here are also the issues of urban and social violence and insecurity, even because of how the subject is mediated. However, there is no work in the school and community context to address such controversial issues that leave strong memories in the lives of the students of that institution and their families.

In situations such as those presented, with losses resulting from violence, there is a huge challenge and a complex psychological process, motivated by the task of dealing with the trauma experienced and the harsh and violent rupture of their presumed world (Gregio et al., 2015). The process of mourning violent death may have a different development, be more complicated and the consequences for mental health may follow a different trajectory, compared to situations of natural death (Kristensen, Weiseth \& Heir, 2012).

Therefore, mourning in situations such as those experienced by participants involves a degree of complexity when dealing with losses due to early, violent deaths or both. It also requires an adequate support network, whether family, social or professional, to assist in the process of dealing with permanent loss. The mental and emotional reorganization is necessary for the readaptation to the new reality without the presence of the estimated person.

\subsection{Communication of death}

It is not difficult to imagine how difficult it is to communicate death to the child. It is not a simple task, since the theme causes fear, anxiety, and restlessness. The expression and popular discourse ensure that "the only certainty during life is death", yet the subject is often avoided. Thus, talking about this issue implies anguish of the news communicator in the face of this condition, especially when it comes to communicating and talking about the subject with the child (Sengik \& Ramos, 2013). In addition to the type of death, violent and premature, another impact factor can be added: the veiled form of omission, secrecy, or family taboo involving the death of someone close to you.

In this research, it was raised and demonstrated in Table 1 that children $\mathrm{C} 2, \mathrm{C} 3$, and $\mathrm{C} 4$ received the news abruptly, without space or any preparation for dialogue due to the circumstances of the news or, still, the communication made by someone close to the child did not happen and the news was given by third parties or by the media (C7, C8, and C9). According to Torres (2012, p.122), the evolution of the child's grieving process, "[...] it is enormously influenced by what is said to it, as it is said, and in the case of the death of one of the parents, how the surviving parent reacts and how he expects the child to react."

The family's understanding of death as a subject impregnated with negative, morbid aspects prevents communication with children because there is the mistaken belief of protection. However, care to spare the child from suffering becomes a barrier to the exploration of feelings generated by loss (Paiva, 2011). It is necessary to recognize that not speaking, lying or the absence of space for the child to express himself/herself ends up generating the perception that he/she is outside the feeling shared by the family; guilt; the erroneous reading of a certain abandonment or, also, the feeling of duty to have to fill the emptiness felt by the family, for the loss of the loved one. For example, in the death of $\mathrm{c} 2$ 's second relative and $\mathrm{C} 3$ 's uncle, the parents tried to lie by saying that the uncle was still alive and in the hospital, gaining some time to also prepare to tell. Both children became suspicious, but in $\mathrm{C} 2$ generated the now constant concern that something might happen, in addition to the tendency to think that the news is worse and always more tragic.

While studying grief in the family and three siblings, Andrade, Mishima-Gomes, and Barbieri (2018) concluded that the way grief is experienced by the child is directly influenced by what she learns about loss, as well as by the opportunities she has to share her thoughts and feelings. In this way, explanations should be given to help them deal with guilt, which can hinder the grieving process. Undoubtedly, if the communicator is a trusted adult of the child and who can talk about death clearly and naturally, he will be helping him in the mourning process (Kovács, 1992). Moreover, talking about the topic will not increase the pain of loss, on the contrary, it tends to decrease it, and, consequently, will make it easier for the child to elaborate his/her grief (Sengik \& Ramos, 2013; Weber, Alvariza, Kreicbergs \& Sveen, 2019).

Psychotherapeutic interventions, in which the child can express his/her grief and the unspoken, through the playful, through the fantasy expressed in his games are important to help him to go through this delicate moment, to return to him the possibility of autonomy and ability to cope with adverse situations of losses (Andrade, Mishima-Gomes \& Barbieri, 2018).

Space is given to the child and the understanding that, even at earlier ages, she already perceives and feels the loss of the loved one are essential aspects for the elaboration of child mourning, even if she has not asked for the deceased, mourners, or demonstrated more perceptible behavioral changes. The lack, the unsaid, the concealment of feelings, or the practice of lying by family members can generate internal conflicts involving ambivalence about the child's fantasies and feelings. 


\subsection{Conflicts and fantasies}

Internal conflicts refer to oppositions about internal demands, such as contradictory feelings about a person who has died and may manifest in symptoms, behavior disorders, and defenses (Laplanche \& Pontalis, 1996). Death is a loss that causes intense internal conflicts in the child, such as missing due to the absence of the loved one and at the same time anger because of the feeling of abandonment triggered by the lack of the loved one. As a way of dealing with an undesirable internal reality, fantasy emerges, and does it as a defensive process, in the search to be able to deal with internal reality, through the use of an omnipotent control of external reality. (Winnicott, 1975/1971).

When discussing the ability to fantasize, Winnicott (2000) turns to the primitive emotional development of the subject. He understands that fantasies arise early and refer to the primitive experiences of each subject, in terms of satisfaction, frustrations, pleasurable and painful sensations of childhood. Fantasies are a psychic process that allows the connection between internal and external realities, as it interweaves contents, objects, and desires.

The same ability to fantasize, which can be a bridge to the passage and interconnection between internal and external realities, can also present moments of interruption of this connection (Winnicott, 1975/1971). Therefore, such capacity can be understood as a healthy aspect of the individual to deal with loss, even if the fantasy is not greater and prevents the perception of reality, being part only of the transitionality necessary to repair what was lost (Barone, 2004). In this sense, this research understands fantasy as a creative and reparative capacity that will culminate in the acceptance of death by the child, in which the concrete experience of death is related to the constitution of fantasies by the child.

In the interpretations of HTP information and interviews, internal conflicts were evidenced, in fantastic terms, through fantasies of guilt, omnipotence, and rejection; as well as the feeling of insecurity derived from the fantasy of abandonment/rejection, as shown below in Table 3. These data are similar to those of the research developed by Franco and Mazorra (2007) with children who lost one of their parents by death, by which one perceives the predominance of the feeling of helplessness as internal conflict and mobilizing fantasies of the threat to their physical and emotional survival.

Table 3 - Fantasies identified.

\begin{tabular}{ccc}
\hline Fantasy & Description & Child \\
\hline Omnipotence & Be strong and save the family & C2, C3 \\
Denial & $\begin{array}{c}\text { Do not need it (person who died) } \\
\text { Never want to remember } \\
\text { Annihilation }\end{array}$ & $\begin{array}{c}\text { Fear of death } \\
\text { Somatization }\end{array}$ \\
Retaliation & Nightmares about the person who died & C1, C4, C9 \\
& To be blamed for the death \\
Fault & Do not prevent death & C2, C3, C5 \\
Identification & Look like the person who died (positive) \\
& Take the place of the person who died & C1, C5, C7, \\
\hline
\end{tabular}

In addition to the diversity of the fantastic contents presented by the research participants, it is necessary to consider both the intensity and duration of such phenomena. It is necessary to emphasize, however, the need to aggregate the aspects that involved the death of a loved one, such as the type of death, the communication of the news, the family dynamics, space is given to mourning, among others, so that it is possible to understand the mourning and fantasies of the child and, whether or not it is in the process of preparing its mourning.

Highlighting some fantasies presented by the children participating in the research can be recorded the expressions of C7, which considers itself like the sister and says: "she liked to draw and I draw just like her" and also that of $\mathrm{C} 2$, a child always very talkative who reports the dream he had with the family, in a mixture of omnipotence, that if he obeyed the order given in the dream no one would die, and fear when dreaming of dead people.

The participant $\mathrm{C} 4$, very insightful, all the time sought to have control in the HTP survey, Was very observant with the questions and, at some point, said: "This question you have already asked, is very similar to the other about this drawing, the answer is the same: I do not remember anything". In a defensive position, he sought to protect himself by denying the importance of loss and the occurrence of death.

Regarding the fantasies, Franco and Mazorra (2007) classified them into three distinct groups: 1) related to the complication, 2) that reflect the elaborative process of mourning, and 3) defense. In this study, the fantasies of guilt, retaliation, and annihilation were identified as hindering the mourning; as a facilitator of identification 
and defense fantasies of omnipotence and denial.

Among the participating children, eight (8) presented some change in behavior with loss, such as low school performance ( $\mathrm{C} 2$ and $\mathrm{C} 3)$, decreased self-esteem $(\mathrm{C} 1, \mathrm{C} 2, \mathrm{C} 4, \mathrm{C} 9, \mathrm{C} 5$, and $\mathrm{C} 7)$, marked anxiety and fainting $(\mathrm{C} 4)$, respiratory problems $(\mathrm{C} 1)$, gastric problems $(\mathrm{C} 9)$, nightmares $(\mathrm{C} 2, \mathrm{C} 3$, and $\mathrm{C} 5)$, sudden crying $(\mathrm{C} 1$, $\mathrm{C} 2, \mathrm{C} 4, \mathrm{C} 5)$ and psychomotor agitation $(\mathrm{C} 3, \mathrm{C} 7$, and $\mathrm{C} 8)$. During the interviews with the guardians, changes in the behavior and relationships of children were reported that were not restricted to the family context. Exemplifying, R2 reported that $\mathrm{C} 3$ went from a happy and kind boy to restless, aggressive with colleagues, and resistant to going to school, with frequent complaints of indiscipline.

On the other hand, the fraternal pair $\mathrm{C} 2$ shows constant concern for the family, has nightmares and school difficulties are beginning and at an important moment of learning, literacy. It is clear to note that although $\mathrm{C} 3$ seeks to demonstrate internal and external strength not befitting his age, expressed as "I am not afraid of anything" or "I never cry" he fears moving away from his mother, manifesting the fantasy of omnipotence. The fear of being alone, or rather away from the mother, is related to a constant threat, because there were many difficulties that the family had to face, and demonstrates the need to be together, as a form of protection for them to remain united.

The fantasies presented by the participants reflect the mourning process, such as the non-acceptance of the loss manifested by denial and the identification with positive characteristics of the deceased person (C7). These manifestations, forms of fantasies, communicate what the child cannot speak. In this sense, for the mourning process to be elaborated, the child must experience the feelings generated by grief. She should be encouraged to express her emotions and feelings, which can occur through playful activities such as drawings, games, and stories.

If the environment, both the family and the external support (friends, school, or other support networks), cannot provide the child with the necessary conditions for their support in the face of loss and suffering, the child has the perception that he does not receive what he needs to believe that the world is a good place. The lack of this illusion of the environment as good can generate difficulties to relate to external reality creatively and manifest the true self.

In the information resulting from the interpretations of HTP and playful interview, conflicts of insecurity and need for support appeared with a certain frequency, but in $\mathrm{C} 1, \mathrm{C} 4, \mathrm{C} 8$, and $\mathrm{C} 9$ it became more evident the difficulty of expressing themselves creatively and the significant inhibition in their responses.

For participant $\mathrm{C} 9$, referred by the school, the death of the friend generated suffering, but another picture came together that, until that moment of referral, had not been identified by the educational institution or by the family: the child presented symptoms consistent with the post-trauma stress picture. The shooting and death generated fear of going to school, which coincided with an attack on a school, much carried out in the national media. It was only after a visit by the researcher in the school unit to address the child bereavement that the local staff began to realize that $\mathrm{C} 9$ began to be absent after the death of the friend, as well as that the child was more withdrawn and distressed.

It is interesting to take, for example, this picture of $\mathrm{C} 9$, to elucidate that the child seeks ways to understand what is happening and to supply the needs that are not being met, communicating this to the environment in the way that he can even by the manifestation of symptoms. Therefore, due attention must be given to this subject, because these symptoms can directly impair the emotional, intellectual and social development of the bereaved child, hindering their relationship with the world and their maturation, in addition to their health.

Also about the environment, it is worth noting that the insecurity experienced in the family dynamics of the child, or the absence of the family as in the case of participants C5 and C6, generates conflicts about expressing opposition or aggressiveness, fearing that the family will not survive their anger and, consequently, lose the affection they have. For the two girls, C5 (guilt and retaliation) and C6 (denial), the conflict and fantasies were manifested for fear of losing contact and the possibility of living with their mother again.

On the other hand, $\mathrm{C} 3$ can express itself through its aggressiveness, but this expression occurs in a regressed and decontextualized manner, lacking the continence of the external environment to help it. This participant demonstrated impaired emotional development, appearing to have more difficulty in separating fantasy and reality. The identified fantasies showed that they were not triggered in such a way as to provide a creative interaction with reality to achieve satisfaction (Barone, 2004). There are few spontaneous attitudes, as well as the offer of limits, on the part of the mother, which allows children $\mathrm{C} 2$ and $\mathrm{C} 3$ to receive restraint from their anguish, helping them to grow with them and to discover themselves.

Children C7 and C8 were always very independent and lonely. It was possible, then, to observe the repression and avoidance of feelings of fraternal rivalry between them and even in the speech about the deceased sister expressed by C7 "Made (sister) some very cool drawings" and C8 "she always made fun of us, she was fun", who quickly move and change the subject. This can harm the development of children, stagnating growth in the face of guilt for being alive and growing, although the sister cannot do so (Lima \& Kovács, 2011).

In this sense, the fear of having harmed in some way who died provokes the feeling of guilt and further 
intensifies the obstacles in the search for the spontaneous and creative expression of the feelings of child C5: "I felt guilty because my grandmother said asked me not to get in their car (Guardianship Council), but I went. Then it happened (death)" - begins to cry. This situation was observed in the participating children, either because the relationship was very close and the loss was deeply felt or because the experience of loss in the family influenced the child to feel identified with the deceased, as occurred with $\mathrm{C} 2$ and $\mathrm{C} 7$. In participant $\mathrm{C} 2$, concern and identification with the cousin arise when talking about the drawing of the person (HTP): "I made my first [...] here she's joking, happy because she doesn't know her father's dead." At another point: "She (cousin) will never meet her father because her aunt was pregnant when he died." The death of the uncle also has repercussions on $\mathrm{C} 2$ thinking about the possibility of being orphaned.

When addressing guilt and its origins in the emotional development of the child, it is important to recognize that in the lack of the object of love and care lies the origin of the feeling of guilt, which has a positive bias if it is not extreme, because from guilt the child turns to fantasizing and creativity to give new meaning to lose, as a gesture of reparation. In the process of reconstitution of this subject, there is a gradual differentiation between what is fact and what is fantasy, between what is guilt and what is reparation, a true restitutive gesture, which will be repeated throughout life (Winnicott, 1983/ 1958; 2005/ 1960).

Therefore, it is important to understand that fantasies are the internal resources that children have to deal with loss. They serve to deny, destroy or repair (Winnicott, 1983/1958), therefore, involve more regressive content, in certain cases, or shortly after death; and less persecution content when close to acceptance. In this way, they can help in the work of mourning towards reality, as long as the child is not glued to fantasy to the detriment or denial of reality. The consequences of death losses during childhood and the possibility of mourning depend on the fantasies regarding those who died and the guilt arising from the loss. When guilt assumes a bias more based on pathology, persecutory guilt prevails despair and self-accusation (Grinberg, 2000). In the cases presented in this article, the fault does not appear linked to persecution contents, but to the fantasy of certain omnipotence, capable of avoiding the loss, that is, of taking control over one's and the situation around them.

In fragile family environments, the child may repress their feelings, resulting in the emergence of fear of death, psychosomatic symptoms, dependence on parents, learning difficulties, and the process of symbolization (Andrade, Mishima-Gomes \& Barbieri, 2018). The environment as a difficulty in the elaboration of child mourning indicates the responsibility and the way to go, to think about better care strategies for children who suffer loss from death. However, it is also necessary to 'think about the other members of the family and the fragility in which it is found.' Its members are also bereaved or, due to previous experiences, may present particular difficulties to face and even address death. These issues reinforce the need to create preventive social care about the vision of death, loss, mourning so that society can assimilate the so popular saying already referenced in this article, as well as the need to work with the family of the bereaved child.

\section{Conclusion}

In this field investigation, it was possible to verify that the type of death, the way it is communicated, and how it is felt in the family have an impact on the way the child goes through the process of mourning. The sudden and violent deaths, the lack of communication and listening of the child, and the compromised family dynamics showed that they contributed to the difficulties presented through fantasies with defense content. It was possible to notice that the external environment exerts great influence on the way children express themselves.

The predominant fantasies were related to omnipotence, with the expression of the desire to change what happened and to protect the family; to guilt, for not having prevented death or for surviving, and for fear of dying. Understanding the fantasies and how they are used by the child - denial, guilt, responsibilities beyond their reach, among others - provides the psychologist with indicators of how the process of mourning is developed, in the sense of repair and direction for new investments, and also of how to raise hypotheses of more serious problems related to grief. Fantasy, equated with creativity, has its positive value in helping/softening the transition of the child between the internal and external world marked by the irreversible loss of the figure of love.

Communication, the space to talk about death, and how loss is experienced by the bereaved child are very important, and games are the way children explore their conflicts involving fear, guilt, anger, among other unwanted feelings. Thus, the exploration of fantasy and the stimulation of creativity through the objects and transitional phenomena present in the play contribute to the repair of loss and maintenance of memories, without the child having to appeal to the denial of lack, avoiding the feeling of helplessness and abandonment and giving new meanings to absence.

Contrary to the collective imaginary, from a very young beginning, children have nodes about death as a lived experience. Life is also made up of farewells and the child can understand that. The fantasy by adults that the child does not assimilate or mobilize with the reality of death is illusory and is nothing more than denial or minimization of this fact. Avoiding talking about death with the child, a very common practice, is extremely harmful because she perceives the events and behaviors, feels confused, and has no one to confirm her 
impressions of what occurs.

Therefore, the more information the child receives, according to his or her age of development, the less painful his/her grief will be. In the cases presented, the results showed that death was not discussed and, when this occurred, it was permeated with a magical aspect, as if death was not a certain end. This certainly may have made the grieving process difficult.

One aspect that drew attention in the research was that referral sources such as schools, health units, and those responsible for children perceived that they needed some help only those who outsourced discontent or sudden change of behavior. Among the most passive, none reached the group by such referrals.

Research on death, especially with children as participants, makes it more difficult to accept to participate, which justifies not having in the literature an expressive number of empirical studies on infant bereavement; a fact that I suggested the need to turn attention to the understanding of the process of child mourning, and, above all, to create work strategies with both the child and the bereaved family.

Finally, it is necessary to suggest strategies and spaces with groups addressing mourning through playful resources, in which children can see that they are not the only ones to go through some loss or have contradictory feelings, and can express their fantasies and fears, as well as help each other.

\section{References}

Aberastury, A. (2012). Psicanálise da Criança: Teoria e Prática. Porto Alegre: Artmed.

Andrade, M. L. de, Mishima-Gomes, F. K. T., \& Barbieri, V. (2018). Children's Grief and Creativity: The Experience of Losing a Sibling. Psico-USF, 23(1): 25-36. Retirado de https://doi.org/10.1590/141382712018230103

Baptista, M. N. (2018). BDS-IJ - Baptist Depression Scale Infant Juvenile. São Paulo: HOGREFE / CETEPP.

Bardin, L. (2011). Análise de conteúdo. São Paulo: Edições 70.

Barone, K. C. (2004). Realidade e luto: um estudo da transicionalidade. São Paulo: Casa do Psicólogo.

Bittencourt, A. L. P., Quintana, A. M., \& Velho, M. T. A. C. (2011). A perda do filho: luto e doação de órgãos. Estudos de Psicologia (Campinas), 28(4): 435-442. Retirado de https://doi.org/10.1590/S0103$166 \times 2011000400004$

Buck, J. N. (2003). HTP Manual e Guia de Interpretação (R. C. Tardivo, trad.). São Paulo: Vetor. (Trabalho original publicado em 1964)

Castro, E. K. de, \& Levandowiski, D. C. (2009). Desenvolvimento emocional normal da criança e do adolescente. In Castro, M. de G. K., \& Stürmer, A. (Orgs.). Crianças e adolescentes em psicoterapia: a abordagem psicanalítica (2009). Porto Alegre: Artmed. (pp. 55 - 74)

Corso, D. L., \& Corso, M. (2006). Fadas no divã: Psicanálise nas histórias infantis. Porto Alegre: Artmed.

Fensterseifer, L.; Werlang, B. S. G. (2009). Apontamentos sobre o status científico das técnicas projetivas. In Villemor-Amaral, A. E.; Werlang, B. S. G. (Orgs.). Atualizações em Métodos Projetivos para Avaliação Psicológica. São Paulo: Casa do Psicólogo (pp. 15- 33).

Franco, M.H.P., \& Mazorra, L. (2007). Criança e luto: vivências fantasmáticas diante da morte do genitor. Estudos de psicologia. (Campinas) [online]. 24 (4): 503-511. Retirado de http://www.scielo. br/scielo.php?pid=S0103-166X2007000400009\&script=s ci_abstract\&tlng=pt.

Freud, S. (2011). Luto e melancolia. In: Freud, S. Sigmund Freud Obras Completas. Vol. 12. Tradução de Marilene Carone. São Paulo: Cosac Naify. (Trabalho original publicado em 1917).

Gregio, C., Casellato, G., Hispagnol, I., Mazorra, L., Manzochi, L. A, Franco, M. H. P., Oliveira, S., \& Torlai, V. O luto desencadeado por desastres (2015). In Franco, M. H. P. (Org.). A intervenção psicológica em emergência: fundamentos para a prática. (2015). São Paulo: Summus.

Grinberg, L. (2000). Culpa e Depressão. Lisboa: Climepsi.

Klein, M. (1996). O luto e suas relações com os estados maníaco-depressivos (1940). In: Klein, M. Amor, culpa e reparação e outros trabalhos (1921-1945). Obras Completas de Melanie Klein. Vol. I, Rio de Janeiro: Imago.

Kovács, M. J. (1992). Morte e desenvolvimento humano. São Paulo: Casa do Psicólogo.

Kristensen, P., Weiseth, L., \& Heir, T. (2012). Bereavement and mental health after sudden and violent losses. Psychiatry: Interpersonal and Biological Processes, 75(1): 76-97. doi: 10.1521/psyc.2012.75.1.76.

Laplanche, J., \& Pontalis, J. B. (1996). Vocabulário da Psicanálise. São Paulo: Martins Fontes.

Lima, V. R., \& Kovács, M. J. (2011). Morte na família: um estudo exploratório acerca da comunicação à criança. Psicologia: Ciência e Profissão, 31(2): 390-405. doi: http://dx.doi.org/10.1590/S1414-98932011000200014

Paiva, L. E. (2011). A arte de falar da morte para crianças: a literatura infantil como recurso para abordar a morte com crianças e educadores. Aparecida, SP: Ideia \& Letras.

Sengik, A. S., \& Ramos, F. B. (2013). Concepção de morte na infância. Psicologia \& Sociedade, 25 (2): $379-387$. Retirado de http://www.scielo.br/pdf/psoc/v25n2/15.pdf.

Soares, E. G. B., \& Mautoni, M. A. de A. G. (2013). Conversando sobre o Luto. São Paulo:Ágora. 
Trinca, W. (1997). Visão geral e atualidade dos procedimentos: apresentação e aplicação. In Formas de investigação clínica em psicologia. São Paulo: Vetor.

Torres, W.C. (2012). A criança diante da morte: desafios. 4ª ed. São Paulo: Casa do Psicólogo.

Weber, M., Alvariza, A., Kreicbergs, U., \& Sveen, J. (2019). Adaptation of a Grief and Communication Family Support Intervention for Parentally Bereaved Families in Sweden. Death Studies. doi.org/10.1080/07481187.2019.1661883.

Winnicott, D. W. (1975). O brincar e a realidade (J. O. A. Abreu \& V. Nobre, trads.). Rio de Janeiro: Imago. (Trabalho original publicado em 1971)

Winnicott, D. W. (1983). Psicanálise do sentimento de culpa. In: Winnicott, D. W. O ambiente e os processos de maturação. Porto Alegre: Artmed, pp. 19 - 30. (Trabalho original publicado em 1958)

Winnicott, D. W. (1983a). Teoria do relacionamento paterno infantil. In: Winnicott, D. W. O Ambiente e os processos de maturação: estudos sobre a teoria do desenvolvimento emocional. Porto Alegre: Artmed, pp. 38-54. (Trabalho original publicado em 1960)

Winnicott, D. W. (1983b). Distorção do ego em termos de verdadeiro e falso self. In: Winnicott, D. W. $O$ Ambiente e os processos de maturação: estudos sobre a teoria do desenvolvimento emocional. Porto Alegre: Artmed, p. 128-139. (Trabalho original publicado em 1960)

Winnicott, C. (1989). D.W.W.: uma reflexão. In: Explorações psicanalíticas. Porto Alegre: Artes Médicas.

Winnicott, D. W. (1997). O efeito da perda sobre as crianças. In: Winnicott, D. W. Winnicott, pensando sobre crianças (M. A. V. Veronese, trad., pp. 64-65). Porto Alegre: Artes Médicas. (Trabalho original publicado em 1968)

Winnicott, D. W. (2000). Da Pediatria à Psicanálise (D. Bogolometz, trad.) Rio de Janeiro: Imago. (Trabalho original publicado em 1958)

Winnicott, D. W. (2005). Agressão, culpa e reparação. In: Winnicott, D. W. Privação e delinqüência. Trad. de Álvaro Cabral. São Paulo: Martins Fontes. (Texto original publicado em 1960)

Worden, J. W. (2013). Aconselhamento do luto e terapia do luto: um manual para o profissional de saúde mental. $4^{a}$ ed. São Paulo: Roca. 